Karakaş Yıldırım, Ö. (2020). 8. sınıf Türkçe ders kitabındaki yazma etkinliklerinin yenilenmiş Bloom taksonomisine göre incelenmesi. Ana Dili Eğitimi Dergisi, 8(2), 315-325.

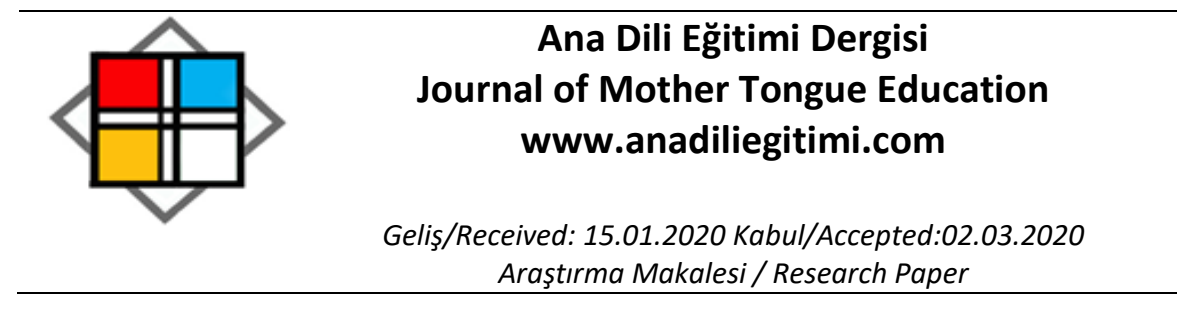

\title{
8. Sınıf Türkçe Ders Kitabındaki Yazma Etkinliklerinin Yenilenmiş Bloom Taksonomisine Göre İncelenmesi *
}

\author{
Özge KARAKAŞ YILDIRIM**
}

Öz

Yeni fikirlerin ortaya çıkmasında etkili olan eleştirel, yaratıcı, yenilikçi ve analitik düşünme gibi üst düzey düşünme becerileri, Türkçe Öğretim Programlarında özellikle vurgulanmaktadır. Yeni eğitim anlayışı ile birlikte, öğrencinin sahip olduğu bilginin değerlendirilmesinden ziyade, bu bilgiyi yaşama transfer etmesinin daha önemli olduğu bilinmektedir. Üst düzey becerilere ulaşmada ders kitaplarında yer alan etkinliklerin hangi bilişsel basamak düzeyine hitap ettiğini bilmek gerekmektedir. Bu sınıflandırmayı yaparken, Bloom'un yenilenmiş taksonomisi dikkate alınmıştır. Araştırmada yenilenmiş Bloom Taksonomisi'nin bilişsel beceri ve bilgi birikimi boyutları dikkate alınarak, yazma etkinliklerinin öğrencilerin üst düzey düşünme becerilerine ne derece katkı sağladığını tespit etmek amaçlanmıştır. Çalışma, nitel araştırma veri toplama tekniklerinden doküman analizi kullanılarak 2018 yılında yayımlanan Türkçe Ders Kitaplarından 8.sınıf düzeyi sınırlılığında gerçekleştirilmiştir. Çalışmada, etkinliklerin \%61'inin alt düzey, \%39'unun ise üst düzey becerilere; doğrudan yazma becerisine yönelik olan, öğrenciden yeni bir şeyler oluşturmasının istendiği etkinliklerin üst düzey beceri basamaklarına (\%32 yaratma), yazma becerisi altında yer alan dil bilgisine yönelik etkinliklerin ise alt düzey beceri basamaklarına (\% 26 hatırlama) hitap ettiği tespit edilmiştir.

Anahtar Kelimeler: öğretim programı, ders kitabı, Bloom taksomonisi, yazma becerisi

\section{Research of Writing Activities in the $8^{\text {th }}$ Grade Turkish Course Book According to the Revised Bloom Taxonomy}

\begin{abstract}
High-level thinking skills such as critical, creative, innovative and analytical thinking that are effective in the emergence of new ideas, are emphasized in the Turkish Teaching Curriculum. With the new educational perspective, the curriculum emphasizes the importance of transferring the knowledge. It is necessary to know that which cognitive step level the activities in the textbooks address in reaching high-level skills. While classifying the activities, Bloom's revised taxonomy is taken into consideration. In the research, it was aimed to determine to what extent the writing activities contributed to the students' high-level thinking skills by considering the cognitive skills and knowledge dimensions of the Revised Bloom Taxonomy. The study was carried out in the limitation of 8th grade level of Turkish Textbooks published in 2018 using document analysis which is one of the qualitative research data collection techniques. As a result of the study, it was determined that $61 \%$ of the writing activities addressed to the lower level and $39 \%$ of them to the upper level skills, and activities related to direct writing skills belong to the upper level skill (32\% creation) and the activities for grammar belong to the lower level skill (26\%recall).
\end{abstract}

Keywords: Curriculum, course book, Bloom taxonomy, writing skill

\footnotetext{
* Bu çalışma, Uluslararası Türk Kültürü Sempozyumunda sunulan sözlü bildirinin geliştirilmiş halidir. 6-8 Aralık 2019, Ankara.

** Doktora öğrencisi, Sakarya Üniversitesi, Eğitim Bilimleri Enstitüsü, Türkçe Eğitimi Bilim Dalı, Sakarya, ozgekarakas@windowslive.com, ORCID: 0000-0002-7838-8880
} 


\section{Giriş}

Günümüz koşullarında sadece akademik bilgi ve beceriye sahip bireylerin değil; düşünebilen, sorgulayabilen, araştırabilen, ulaştığı bilginin doğruluğunu eleştirel açıdan ele alabilen, sıralama, sınıflama becerilerine sahip bireylerin yetiştirilmesi ön plana çıkmaktadır. Bu amaçla hazırlanan müfredat programları, sadece o derse ait müfredatı vermek yerine, öğrencilere birtakım üst düzey becerileri de kazandırmayı hedeflemektedir. Cumhuriyet'in ilk yıllarından itibaren, yenilenen ve geliştirilen Türkçe Öğretim Programlarında ilk başlarda sadece "ana dili derslerinin sene sene nasıl işleneceği konu ve yöntem olarak tarif edilirken" (MEB, 1922; akt: Benzer, 2017: 305;) 2006 Türkçe Öğretimi Programı ile birlikte müfredat dışı bazı becerilerin kazandırılması da önem kazanmıştır. 2006 Türkçe Öğretim Programının genel amaçlarında bu durum açıkça ifade edilmiştir: "Türkçe Dersi Öğretim Programı ile Türk Millî Eğitiminin genel amaçları ve temel ilkelerine uygun olarak öğrencilerin; anlama, sıralama, ilişki kurma, sınıflama, sorgulama, eleştirme, tahmin etme, analizsentez yapma, yorumlama ve değerlendirme becerilerini geliştirmelerinin yanında yapıcı, yaratıcı, akılcı, eleştirel ve doğru düşünme yollarını öğrenmeleri, bunları bir alışkanlık hâline getirmeleri amaçlanmaktadır" (MEB, 2006: 4). Yine aynı programda dil becerilerinin yanı sıra öğrencilere kazandırılması gereken temel beceriler içinde "eleştirel düşünme, yaratıcı düşünme, problem çözme, karar verme" gibi üst düzey düşünme becerilerine de yer verilmiştir. 2018 Türkçe Öğretim Programında ise hızla gelişen ve değişen toplumun bilgiyi üreten, hayatta işlevsel olarak kullanabilen, problem çözebilen, eleştirel düşünen, girişimci, kararlı, iletişim becerilerine sahip, empati yapabilen, topluma ve kültüre katkı sağlayan bireylere ihtiyaç duyduğu ve bu bireylerin yetişmesi için de öğretim programlarının sadece bilgi aktaran bir yaklaşımdan ziyade bireysel farklılıklara odaklı, değer ve beceri kazandırma hedefli bir yapıda olması üzerinde durulmuştur (MEB, 2018).

\section{Dil ve Düşünme Becerileri}

Dil; iletişimde, eğitimde, meslek hayatında, sosyal ve toplumsal yaşamda, kısacası hayatımızın her alanında bulunduğumuz ortamı anlamamızı ve kendimizi bu ortamlarda doğru bir şekilde ifade etmemizi sağlayan en önemli güçtür. Duygularımızı, düşüncelerimizi, hayallerimizi yazmak, çizmek, konuşmak gibi farklı kanallarla ifade edebiliriz. Dil, insana kendisini ifade etmede sınırsız kapılar açan ve en sık tercih edilen yoldur. Bu açıdan baktığımızda önemli ve etkili bir iletişim aracı olarak gördüğümüz dil, düşünmede de etkin ve önemli bir yere sahiptir. "Deneyimler bağlamında diyalektik bir biçimde gelişen bilgi inşa sürecinin önemli bir parçası" (Çakır, 2013: 4) olan düşünceler, "...dille açıklanmakta, somutlaştırılmakta ve paylaşılmaktadır. Dil; düşünmenin mantığını, kavramlarını, ilkelerini ve yargılarını belirlemektedir" (Güneş, 2012: 131). Dil ve düşünce arasında sonsuz bir etkileşim vardır. Her ikisi de birbirini beslemekte ve etkilemektedir. Dil ile düşünme arasındaki bu etkileşimli bağ, ister istemez ana dili öğreniminde de düşünme becerilerinin gerekliliğini ve önemini vurgulamaktadır. Düşünme becerilerinin gelişiminde aktif bir rol oynayan ana dili derslerinde sadece temel dil becerilerinin eğitimi verilmemekte, aynı zamanda düşünme becerilerinin eğitimi de önemsenmektedir. Üzerinde bu kadar çok durulan düşünme becerilerini her ne kadar bir çaba içine girmeden yapıyor olsak da bu durum yeterince etkili düşünebiliyor olduğumuz anlamına gelmemektedir (Nickerson, 1988). Bu da düşünme becerisinin, özellikle üst düzey düşünme becerilerinin eğitim ve öğretimle desteklenmesi gerektiği hususunu ön plana çıkarmaktadır. Hayatımızın her anında olan düşünme becerilerini “...aktif olarak kullanabilen bireyler, mesleki ve sosyal ilişkileri gibi pek çok alanda başarılarına başarı katacaktır. Aynı zamanda düşünme becerileri gelişmeyen bireylerin; mukayese, yorumlama, değerlendirme gibi aşamalarda hata yapmaları ya da başarısız olmaları kaçınılmaz olacaktır. Bu nedenle eğitim programları düşünme becerilerini geliştirmeye yönelik olarak hazırlanmalıdır (Yıldız, 2015b: 73). Nitekim öğrenen merkezli bir eğitim anlayışının uygulanmaya başlamasıyla birlikte öğrenme sürecinde öğrenenin zihinsel aktivitelerinin önem kazandığı son yıllarda, birbirleriyle karşıııkı bir etkileşim içerisinde olan ve "birbirlerinin gelişimine katkıda bulunup aralarında çok yönlü bir ilişki olan..." (Yıldız, 2015a: 480) dil ve düşünme becerilerinin geliştirilmesi, modern eğitim yaklaşımlarının en önemli amacı olmuştur. Aydın ve Yılmaz'ın (2010) fen alanında yapmış oldukları çalışmada, yapılandırmacılık temelinde yürütülen ders süreci sonunda öğrencilerin üst düzey bilişsel becerileri kazanmada geleneksel eğitimle yürütülen 

incelenmesi

ders sürecindeki öğrencilere nazaran daha başarılı oldukları sonucuna ulaşılmıştır. Mecit'in (2006) 5. sınıf öğrencileriyle yaptığı çalışmada ise 7E öğrenme modelinin öğrencilerin eleştirel düşünme becerisini geliştirdiği sonucuna ulaşılmıştır. Yapılandırmacılık ve üst düzey düşünme becerilerinin ilişkisini vurgulayan çalışmalar dışında, yapılandırmacılığın esas alındığı öğretim programlarında da üst düzey düşünme becerilerinin sıklıkla vurgulandığı dikkat çekmektedir. Örneğin, Türkçe Öğretim Programında, Türkçe öğretiminin amacının "sadece dil becerilerinin geliştirilmesi değil, aynı zamanda sınıflama, sorgulama, eşleştirme, çözümleme, birleştirme, ilişki kurma, değerlendirme, anlamlandırma gibi zihinsel birtakım becerilerin geliştirilmesi olarak belirtilmiştir" (Güneş, 2013; Durukan ve Demir, 2017). "Zihinsel becerilerin kalbi olan düşünme ve sorgulama, bireyin zihinsel işlem ve süreçlerini harekete geçirmekte, problem çözme, karar verme ve kavramlaştırma becerilerini geliştirmektedir. Böylece öğrenmeyi öğrenme, yaratıcı düşünme, eleştirel düşünme, yansıtıcı düşünme gibi üst düzey beceriler daha hızlı geliştirilmektedir" (Güneş, 2012: 128). Bu noktada, üst düzey düşünmenin ne olduğuna değinmek gerekirse, karmaşık zihinsel süreçleri içeren üst düzey düşünme, araştırmayı, sorgulamayı, elde edilen bilgiler arasında zihinsel bağ kurabilmeyi ve sınıflama yapabilmeyi gerektiren bir düşünme biçimidir. Ayrıca, üst düzey düşünme becerileri; analitik düşünme, bir yargıya varma, açık fikirli ve yenilikçi olma, farklı durumlara uyum sağlayabilme, karar verme, organize olabilme, plan yapma, eleştirel ve yaratıcı düşünme gibi çeşitli zihinsel etkinlikleri de beraberinde getirmektedir. 2006 Türkçe Öğretim Programında temel beceriler altında, 2018 Türkçe Öğretim Programında Türkiye Yeterlikler Çerçevesinde ele alınan becerilerin, bireylerin diğer insanlarla uyum ve mutluluk içinde yaşayabilmeleri için geliştirilmesi gerektiği üzerinde durulmuştur.

Üst düzey düşünmenin gelişmesine katkı sağlayan dil becerilerinden biri olan yazma, uygulanma esnasında birtakım üst düzey düşünme becerilerini gerektirmektedir. Yazma; duygu, düşünce ve hayallerin birtakım semboller aracılı̆̆ıyla aktarılmasıdır. "Kişinin kendini aktarma isteğinin sonucu olarak gerçekleşen yazma işi, esasen düşüncenin dışa vurumudur" (Karadağ ve Maden, 2014: 266). Her dil becerisi, zihinsel becerileri geliştirmede önemli bir etkiye sahiptir ancak üretme, sorgulama, geliştirme, yeni düşünceler ortaya koyma gibi beceriler içeren yazma, üst düzey düşünme becerilerinin gelişimine daha fazla katkı sağlamaktadır. "Çünkü yazmada kullanılan zihinsel işlemler aynı zamanda zihin yapısını düzenleyen işlemler olmaktadır" (Güneş, 2013: 159). Üst düzey düşünme becerilerinin kazandırılmasında, ders sürecinde kullanılan materyal ve ölçme değerlendirme uygulamalarının da bu becerileri geliştirmeye yönelik olması gerekmektedir. Bu sebeple öğrencileri üst düzey düşünmeye sevk edecek etkinlik ve soruların seçilmesi önemlidir.

\section{Yenilenmiş Bloom Taksonomisi}

Bilişsel anlamda, ölçme değerlendirme ve etkinlikleri sınıflandırabileceğimiz ilk taksonomi, adıyla özdeşleşmiş olan Bloom'a aittir. "Taksonominin ana fikri, eğitimcilerin, öğrencilerin bilmesini istediklerini basitten karmaşığa bir hiyerarşide düzenleyebiliyor olmalarıdır" (Huitt, 2011). Bilişsel alandaki ilk sınıflama olarak bilinen Bloom taksonomisi, "Chicago Üniversitesi'nin Sınav Kurulu Direktörü olan Benjamin S. Bloom'un liderliğinde bir çalışma grubu tarafından sınav hazırlama konusunda harcanan emeği azaltacağı düşünülerek ortaya atılmıştır. Birkaç kez toplanan bu çalışma grubunun yaptıkları 1956 yılında "Eğitim Hedeflerinin Sınıflaması: El Kitabı I: Bilişsel Alan(Taxonomy of Educational Objectives: Handbook I: Cognitive Domain)" ismiyle kitap olarak yayımlanmıştır" (Krathwohl, 2002: 212). Bu kitaptaki sınıflama orijinal taksonomi olarak geçmektedir. Orijinal taksonomi, bilgi, kavrama, uygulama, analiz, sentez ve değerlendirme olmak üzere toplam altı bilişsel basamak içermektedir. Kategoriler basitten karmaşığa doğru sıralanmaktadır (Bloom ve diğerleri, 1956; Krathwohl, 2002; Bümen, 2007; Başbay, 2008; Demir, 2015). Çok uzun yıllar kullanılan orijinal taksonomi, üst basamakların gerçekleştirilebilmesi için alt basamakların gerçekleştirilmiş olması, sentez basamağının değerlendirme basamağını da kapsıyor olması gibi eleştiriler almıştır. Ayrıca "aradan geçen zamanda teknoloji ve diğer alanlardaki gelişme ve değişime uyarlanması ihtiyacı"(Beyreli ve Sönmez, 2017: 216) da değişikliği kaçınılmaz kılmıştır. Bunun üzerine 1995 yılında başlanan çalışmalar sonucunda 1997 yılında yeni sınıflamanın taslağı oluşturulmuştur (Anderson, 1999). 1995-2000 yılları arasında sürdürülen bu çalışmaların sonuçları; Anderson ve Krathwohl editörlüğünde Öğrenme, Öğretme ve Değerlendirme İçin Bir Sınıflama: Eğitim Hedeflerinin Bloom 
Taksonomosinin Yenilenmesi (A Taxonomy for Learning, Teaching and Assessing: A Revision of Bloom's Taxonomy of Educational Objectives) ismi ile yayımlanmıştır (Anderson, 2005). Yenilenmiş taksonomideki en önemli değişiklik, sadece bilişsel süreç basamaklarını içeren ve tek boyutlu olarak anılan taksonominin iki boyutlu bir yapıya dönüştürülmesidir. "Bu boyutlardan biri bilgi boyutunu (öğrenilecek bilginin türü), diğeri ise bilişsel süreç boyutunu (öğrenmek için kullanılan süreci) tanımlar" (Forehand, 2010). "Bu iki boyut birbiriyle ilişkili olup öğrenci, süreç boyutunun herhangi bir aşamasında bilgi boyutundaki dört çeşit bilgiyi de kullanabilmektedir" (Aslan, 2011: 238). Süreç boyutu içinde hatırlamak, anlamak, uygulamak, analiz etmek, değerlendirmek ve yaratmak adlarında eylem yapısında altı farklı kategori yer alırken; bilgi boyutunda ise olgusal, kavramsal, işlemsel ve üst bilişsel olmak üzere dört farklı bilgi türünü içeren kategoriler verilmektedir.

Tablo 1.

Orijinal Bloom Taksonomisinin Bilişsel Basamaklarının Yenilenmiş Bloom Taksonomisindeki Karşılıkları

\begin{tabular}{ll}
\hline Orijinal Bloom Taksonomisi & Yenilenmiş Bloom Taksonomisi \\
\hline Bilgi & Hatırlama \\
Kavrama & Anlama \\
Uygulama & Uygulama \\
Analiz & Çözümleme \\
Sentez & Değerlendirme \\
Değerlendirme & Yaratma \\
\hline
\end{tabular}

Tablo 1'de Orijinal Bloom taksonomisinin bilişsel basamaklarının Yenilenmiş Bloom Taksonomisindeki karşılıkları verilmiştir. Orijinal Bloom taksonomisinde yer alan "bilgi, kavrama, uygulama, analiz, sentez, değerlendirme" basamakları; Yenilenmiş Bloom taksonomisinde "hatırlama, anlama, uygulama, çözümleme, değerlendirme, yaratma" şeklinde revize edilmiştir. "iki üst düzey ve en karmaşık basamaklar olan Sentez (Synthesis) ve Değerlendirme (Evaluation) basamakları, Değerlendirme (Evaluating) ve Yaratma (Creating) olarak tekrar isimlendirilmişlerdir (Anderson ve Krathwohl, 2001). Huitt (2011)'e göre, bu en yüksek iki düzey karmaşıklık konusunda birbirine eş değerdir. Her ikisi de temel bir süreç olarak çözümleme (analyzing) basamağına bağlıdır ve sentez (synthesis) veya yaratma (creating) parçaların yeni ve orijinal bir şekilde yeniden düzenlenmesini gerektirirken, değerlendirme (Evaluation/evaluating) iyi, daha iyi veya en iyiyi bir standartla karşılaştırmayı gerektirir.

Üst düzey düşünme becerilerinin geliştirilmesi ve değerlendirilmesinde Bloom taksonomisinden sıklıkla faydalanılmaktadır. Bu çalışmada, yenilenmiş Bloom Taksonomisi'nin bilişsel beceri basamakları ve bilgi boyutu sınırlılı̆ında 8.Sınıf Türkçe Ders Kitabında yer alan yazma etkinliklerinin öğrencilerin üst düzey düşünme becerilerine ne derece katkı sağladığını, yazma etkinliklerindeki bilişsel beceri basamaklarının ve öğrenilen bilgi türünün dağıımını tespit etmek amaçlanmıştır.

Tablo 2.

Bloom Taksonomisinde Bilişsel Basamakların Düzeylere Göre Dağılımı

\begin{tabular}{ll}
\hline Alt Düzey Bilişsel Beceri Basamakları & Üst Düzey Bilişsel Beceri Basamakları \\
\hline Hatırlama & Çözümleme \\
Anlama & Değerlendirme \\
Uygulama & Yaratma \\
\hline
\end{tabular}

Tablo 2'de Bloom Taksonomisinde bilişsel basamakların düzeylere göre dağılımına yer verilmiştir. 
8. sınıf Türkçe ders kitabında yer alan yazma etkinliklerinin yenilenmiş Bloom taksonomisine göre incelenmesi

\section{Araştırmanın Modeli}

\section{Yöntem}

Yenilenmiş Bloom Taksonomisi'nin bilişsel beceri ve bilgi birikimi boyutları dikkate alınarak, 8 . Sınıf Türkçe Ders Kitabında yer alan yazma etkinliklerinin öğrencilerin üst düzey düşünme becerilerine ne derece katkı sağladığını tespit etmeyi amaçlayan bu çalışma, nitel araştırma özelliği taşımaktadır. Nitel araştırma, "sosyal ya da beşeri bir probleme bireylerin veya grupların atfettiği anlamları keşfetme ve anlamaya yönelik bir yaklaşımdır" (Creswell, 2017: 4). "...psikolojik ölçümler ve sosyal olaylarla ilgili nicel araştırma yöntemlerine göre daha derinlemesine bilgi sağlayan nitel araştırmalar, araştırmacıya konu hakkında daha geniş bir bakış açısı kazandırır" (Büyüköztürk ve diğerleri, 2013: 234).

\section{Çalışma Materyali}

Çalışmanın örneklemini 2018 yılında yayımlanmış olan 8. Sınıf Türkçe Ders Kitabı içinde yer alan yazma etkinlikleri oluşturmaktadır. Etkinlikler, Yenilenmiş Bloom Taksonomisi'nin bilişsel beceri basamakları ve bilgi boyutu sınırlıı̆ı̆nda ele alınmıştır.

\section{İşlem / Verilerin Toplanması}

Bu çalışmada veri toplama yöntemlerinden doküman incelemesi kullanılmıştır. "Doküman incelemesi, araştırıması hedeflenen olgu veya olgular hakkında yazılı materyallerin analizini kapsar. Nitel araştırmalarda doküman incelemesi tek başına bir veri toplama yöntemi olabileceği gibi diğer veri toplama yöntemleri ile birlikte de kullanılabilir" (Yıldırım ve Şimşek, 2013: 217).

\section{Verilerin Analizi}

Verilerin analizinde nitel veri analiz yöntemlerinden betimsel analiz kullanılmıştır. "Bu yaklaşıma göre elde edilen veriler, daha önce belirlenen temalara göre özetlenir ve yorumlanır. Elde edilen veriler önce sistematik ve açık bir biçimde betimlenir. Daha sonra yapılan bu betimlemeler açıklanır ve yorumlanır, neden-sonuç ilişkileri irdelenir ve birtakım sonuçlara ulaşııı" (Yıldırım ve Şimşek, 2013: 256).

\section{Bulgular}

8. Sınıf Türkçe Ders Kitabında yazma becerisi altında programdaki kazanımlarla örtüşen toplam 65 etkinlik vardır. Bu etkinliklerin \%54'ü $(\mathrm{f}=35)$ doğrudan yazmaya yönelik etkinliklerden oluşurken, $\% 46$ 'sı ( $f=30$ ) ise yazma becerisi altında verilen dil bilgisi kazanımlarına yönelik etkinliklerdir.

Tablo 3.

8. Sınıf Türkçe Ders Kitabında Yer Alan Yazma Etkinliklerinin Yenilenmiş Bloom Taksonomisinin Bilişsel Beceri Basamaklarına Göre Dağııımı

\begin{tabular}{|c|c|c|c|c|c|c|}
\hline \multirow[b]{2}{*}{ Tema } & \multicolumn{6}{|c|}{ Bloom Taksonomisinin Yenilenmiş Bilişsel Basamakları } \\
\hline & Hatırlama & Anlama & Uygulama & Çözümleme & Değerlendirme & Yaratma \\
\hline 1.Tema & - & - & 2 & - & 2 & 2 \\
\hline 2.Tema & 3 & - & 2 & - & - & 4 \\
\hline 3.Tema & 5 & 2 & 3 & - & 2 & 2 \\
\hline 4.Tema & 5 & 3 & 1 & - & 1 & 3 \\
\hline 5.Tema & 4 & 1 & 4 & - & - & 3 \\
\hline 6.Tema & 3 & 3 & 4 & - & - & 4 \\
\hline 7.Tema & - & - & 1 & - & - & 4 \\
\hline 8.Tema & - & - & 1 & - & - & 3 \\
\hline Toplam & 20 & 9 & 18 & - & 5 & 25 \\
\hline
\end{tabular}


Tablo 3'te 8. Sınıf Türkçe Ders Kitabında yer alan yazma etkinliklerinin yenilenmiş Bloom taksonomisinin bilişsel beceri basamaklarına göre dağılımı verilmiştir. Tabloyu incelediğimizde, çözümleme basamağında hiçbir etkinliğin olmadığı dikkat çekmektedir. Her temada en az bir etkinlikte karşılık bulan bilişsel beceri basamakları uygulama ve yaratmadır. En fazla yaratma, en az değerlendirme basamağında etkinliğin yer aldığı, çözümleme basamağını karşılayan hiçbir etkinlik olmadığı dikkat çekmektedir. Etkinliklerin \%32'si ( $f=25)$ yaratma, \%26'sı ( $f=20)$ hatırlama, \% 23'ü $(\mathrm{f}=18)$ uygulama, \%12'si $(\mathrm{f}=9)$ anlama, $\% 6^{\prime} \mathrm{sı}(\mathrm{f}=5)$ değerlendirme basamağındadır. En fazla yaratma basamağında yer alan etkinliklerin yeni bir ürün ortaya koyma, üretme, oluşturma gibi becerilerden; içerik olarak da deneme, mektup, fabl, haber metni, hikâye edici metinler, şiir yazmayı içeren etkinliklerden oluştuğu tespit edilmiştir. Hatırlama basamağındaki etkinliklerin ise yazma becerisi altında verilen dil bilgisi kazanımlarına yönelik seçme, hatırlama, bilme, tespit etme gibi becerileri içeren etkinlikler olduğu görülmüştür. Anlama basamağındaki etkinlikler de dil bilgisi kazanımlarına yönelik dönüştürme, anlama, yorumlama gibi becerileri gerektiren ve yapmış oldukları araştırmaları ortaya koymayı içeren; düzenlemek, tespit etmek, rapor etmek, incelemek, sıralamak gibi becerilere hitap eden etkinliklerden oluşmaktadır. Uygulama basamağındaki etkinlikler genellikle bir örnek verilip o örnekteki gibi bir uygulama yapmalarının istenmesi (verilen dilekçe örneğini dikkate alarak dilekçe yazma gibi) veya oluşturdukları metinleri düzenlemeye yönelik üzerinde değişiklik yapma, düzenleme gibi becerileri içeren etkinliklerdir. Değerlendirme basamağındaki etkinlikler, öğrencilerin herhangi bir konuya yönelik görüşlerini yazılı olarak ifade ettikleri değerini belirlemek, açık ve kesin ifade etmek, tavsiye etmek, önem sırasına göre sıralamak gibi becerileri içeren etkinliklerdir. Ayrıca öğrencilerden kendi yazılarını değerlendirmelerinin istendiği değerlendirme basamağına giren etkinlikler de vardır.

Tablo 4.

8. Sınıf Türkçe Ders Kitabında Yer Alan Yazma Etkinliklerinin Alt- Üst Düzey Bilişsel Beceri Basamaklarına Göre Dağılımı

\begin{tabular}{lccc}
\hline Tema & Alt Düzey Bilişsel Beceri Basamakları & Üst Düzey Bilişsel Beceri Basamakları & Toplam \\
\hline 1.Tema & 2 & 4 & 6 \\
2.Tema & 5 & 4 & 9 \\
3.Tema & 10 & 4 & 14 \\
4.Tema & 9 & 4 & 13 \\
5.Tema & 9 & 3 & 12 \\
6.Tema & 10 & 4 & 14 \\
7.Tema & 1 & 4 & 5 \\
8.Tema & 1 & 3 & 4 \\
\hline Toplam & 47 & 30 & 77 \\
\hline
\end{tabular}

Tablo 4'te 8. Sınıf Türkçe Ders Kitabında yer alan yazma etkinliklerinin alt-üst düzey bilişsel beceri basamaklarına göre dağılımına yer verilmiştir. Tabloyu incelediğimizde, etkinliklerin \%61'inin $(f=47)$ alt düzey, \%39'unun ( $f=30$ ) üst düzey bilişsel beceri basamaklarına dâhil olduğu görülmektedir. Yine tabloyu incelediğimizde yazma becerisine yönelik en fazla etkinliğin 3. ve 6. temalarda yer aldığı dikkat çekmektedir. En az etkinliğin ise 8. temada yer aldığı görülmektedir. Özellikle 7. ve 8. temalarda anlatım bozukluğunu bulmaya yönelik çok fazla etkinliğe yer verildiğinden ve 8 . sınıflara yönelik yazma becerisi altındaki kazanımlarda anlatım bozuklukları ile ilgili kazanım olmadığından bu etkinlikler çalışmaya dâhil edilmemiştir. 3., 4., 5. ve 6. temalarda alt düzey bilişsel beceri basamaklarına hitap eden etkinlik sayısının fazla olduğu, alt düzey bilişsel beceri basamaklarına ait etkinliklerin her temada farklı sayılarda yer aldığı, üst düzey bilişsel beceri basamaklarına ait etkinliklerin ise temalara orantılı dağılmış olduğu görülmüştür. 
8. sınıf Türkçe ders kitabında yer alan yazma etkinliklerinin yenilenmiş Bloom taksonomisine göre incelenmesi

Tablo 5.

8. Sınıf Türkçe Ders Kitabında Yer Alan Yazma Etkinliklerinin Yenilenmiş Bloom Taksonomisinde Bulunan Bilgi Birikimi Boyutu ve Bilişsel Süreç Boyutu Basamaklarına Dağılımı

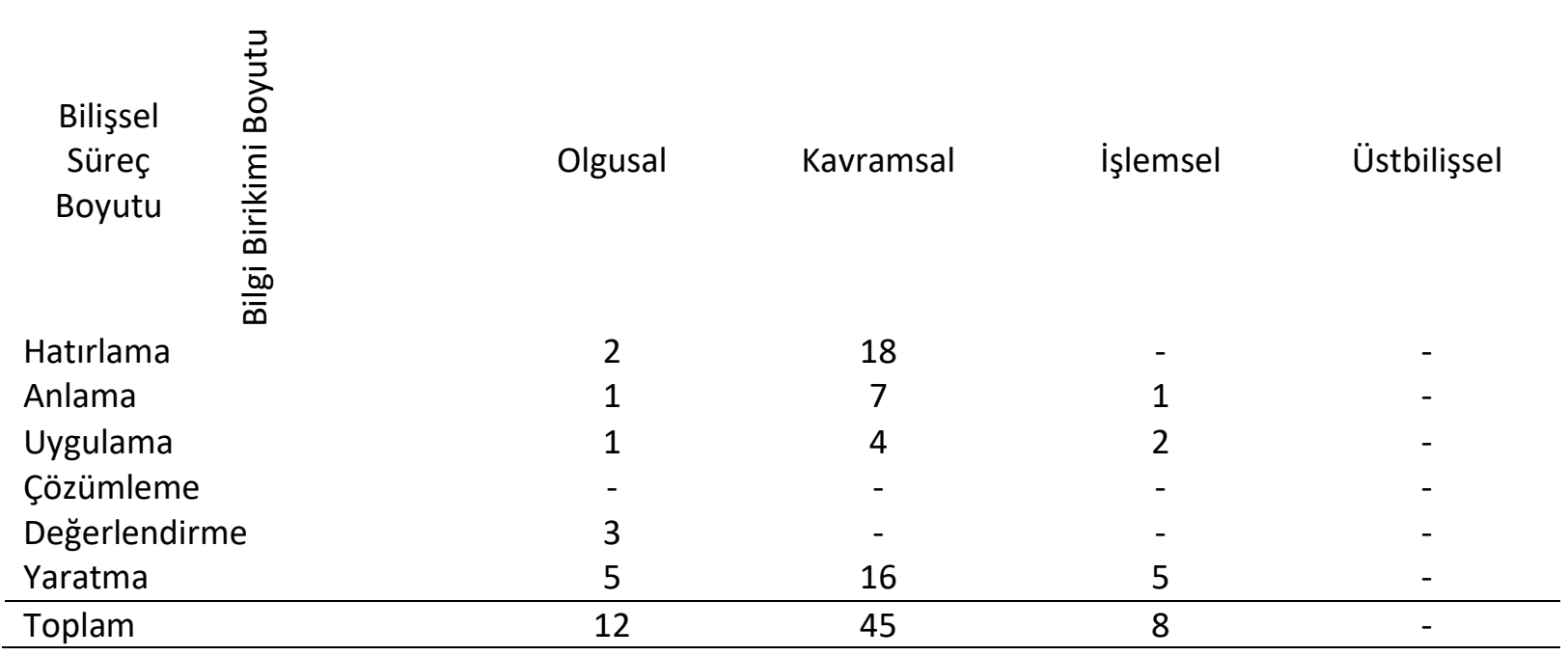

Tablo 5'te 8. Sınıf Türkçe Ders Kitabında yer alan yazma etkinliklerinin Bloom taksonomisinde bulunan bilgi birikimi boyutu ve bilişsel süreç basamaklarına göre dağılımına yer verilmiştir. Tabloya göre, 8.Sınıf Türkçe Ders kitabındaki yazma etkinlikleri içinde bilgi birikimi boyutlarından olgusal, kavramsal ve işlemsel bilgi gruplarında etkinliklerin olduğu, üst bilişsel bilgi grubuna yönelik herhangi bir etkinlik olmadığı görülmüştür. Yazma becerisine yönelik 65 etkinliğin $\% 70$ inin $(f=45)$ kavramsal bilgi grubunda, \%18'inin ( $f=12$ ) olgusal bilgi grubunda ve \%12'sinin ( $f=8)$ işlemsel bilgi grubunda olduğu tespit edilmiştir. Bir konunun kapsamını tanıyabilen öğrencinin noktalama işaretleri, teknik kavramlar gibi temel bilgileri bilmesini gerektiren etkinlikler olgusal bilgi grubunda; daha kapsamlı ve karmaşık bir bütünün temel parçaları arasında eş güdümlü ilişkiyi sağlayabilen öğrencinin farklı edebi türlere yönelik bilgi, cümleyi oluşturan ögelerin bilgisi, kurallı ve devrik cümle bilgisi dâhilindeki etkinlikler kavramsal bilgi grubunda; bir şeyin nasıl yapılacağına dair bilgiyi içeren, yol, yöntem gösteren etkinlikler de işlemsel bilgi (Ulum, 2017) grubunda ele alınmıştır. Metin türü, cümlenin yapısına yönelik bilgilerin çok fazla etkinlikte yer alması, kavramsal bilgi boyutundaki etkinliklerin diğerlerine oranla daha fazla sayıda olmasının sebebidir. Bilgi birikim boyutunun bilişsel süreç basamaklarına dağılımına baktığımızda ise, olgusal bilgi grubundaki en fazla etkinliğin \%42 ( $f=5)$ oranında yaratma basamağında, en az etkinliğin ise $\% 8(\mathrm{f}=1)$ oranında anlama ve uygulama basamağında yer aldığı görülmüştür. Kavramsal bilgi grubundaki en fazla etkinliğin \%40 ( $f=18)$ oranında hatırlama ve \%36 ( $f=16)$ oranında yaratma basamağında, en az etkinliğin ise $\% 9(f=4)$ oranında uygulama basamağında yer aldığı tespit edilmiştir. Işlemsel bilgi boyutunda ise en fazla etkinliğin \%63 $(f=5)$ oranında yaratma basamağında, en az etkinliğin ise \%13 $(f=1)$ oranında anlama basamağında yer aldığı görülmüştür.

\section{Tartışma, Sonuç ve Öneriler}

8. sınıf Türkçe Ders Kitabındaki yazma etkinliklerinin Bloom taksonomisinin bilişsel beceri basamaklarına ve bilgi boyutuna göre incelendiği bu araştırmada, yazma etkinliklerinin en fazla (\%32) yaratma basamağında olduğu, en az (\%6) değerlendirme basamağında olduğu, yaratma basamağındaki çalışmaların üretmeye, yeni bir şeyler oluşturmaya yönelik çalışmalar olduğu, hatırlama basamağındaki etkinliklerin yazma becerisi altında verilen dil bilgisi kazanımlarına yönelik olduğu tespit edilmiştir. Etkinliklerin \%61'inin alt düzey, \%39'unun üst düzey bilişsel basamaklara ait olduğu tespit edilmiştir. Doğrudan yazma becerisini geliştirmeye yönelik etkinliklerin üst düzey bilişsel basamaklara yönelik etkinlikler olduğu ancak dil bilgisi ile ilgili etkinliklerin ise, genellikle seçme, bilme, hatırlama, anlama, yorumlama gibi becerileri gerektiren alt düzey bilişsel basamaklara yönelik olduğu görülmüştür. Doğrudan cümlenin ögelerini ya da fiilde çatıyı bulmaya, işaretlemeye 
ve bilmeye yönelik çalışmaların hatırlama basamağında olduğu tespit edilmiştir. Dil bilgisi etkinliklerini dışarda tuttuğumuz takdirde üst düzey bilişsel becerileri geliştirecek yapıda etkinlik dizisi sunan kitap, dil bilgisi etkinliklerinin devreye girmesiyle alt düzey bilişsel becerilere daha çok hitap eder olmuştur. Öğrencileri analitik, eleştirel, yaratıcı düşünmeye sevk edebilecek etkinliklerin az olduğu tespit edilmiştir. Nitekim Eroğlu'nun (2013) dil bilgisi etkinliklerini Bloom taksonomisine göre incelediği çalışmasında da dil bilgisi etkinliklerinin alt düzey bilişsel becerilere hitap ettiği, üst düzey bilişsel basamağa karşılık gelen hiçbir etkinliğin olmadığı ortaya konmuştur. Durukan ve Demir (2017), yenilenmiş Bloom taksonomisine göre 6,7 ve 8 . sınıf çalışma kitaplarını inceledikleri çalışmalarında, çalışma kitaplarındaki etkinliklerin daha çok hatırlama ve anlama basamağında yoğunlaşmış olduğunu bulmuşlardır. Bu çalışmalardan farklı olarak Türkçe sınav sorularının Bloom taksonomisine göre incelendiği Yıldız'ın (2015a) çalışmasında da sonuç diğer çalışmalardan çok farklı olmamıştır: Soruların çoğunlukla bilgi boyutunda kavramsal bilgi, bilişsel süreç boyutunda ise anlama basamağında olduğu tespit edilmiştir. Ulum'un ( 2017) 2., 3. ve 4. sınıf kitaplarındaki etkinlikleri Bloom taksonomisi çerçevesinde incelediği çalışmasında ise etkinliklerin üst düzey bilişsel becerilerden ziyade alt düzey bilişsel becerilere hitap ettiği ortaya konmuştur. Bilgi boyutu açısından olgusal, kavramsal ve işlemsel bilgi boyutunda etkinliklerin olduğu ancak üst bilişsel bilgi boyutuna yönelik hiçbir etkinliğin olmadığı, en fazla kavramsal bilgi boyutunda etkinliklerin olduğu tespit edilmiştir. Yine Ulum'un (2017) çalışmasında da 2., 3. ve 4. Sınıf Türkçe Ders Kitaplarındaki etkinliklerin büyük çoğunluğunun olgusal ve kavramsal bilgi boyutunda olduğu ortaya konmuştur. Yazma etkinliklerinin dağılımında özellikle 6 ve 7. sınıflarda yoğunluk varken, 8 . sınıf düzeyinde etkinlik sayısının azaldığı görülmüştür. Bu durum da 8. sınıfta özellikle anlatım bozukluklarına yönelik etkinliğe çok fazla yer verilmesi ancak programda 8. sınıf yazma becerisi altında anlatım bozukluklarına yönelik kazanımların olmaması sebebiyle bunların çalışmaya dahil edilmemesinden kaynaklanmaktadır. Programda üst düzey bilişsel becerilerin vurgulanmasına rağmen, 8.Sınıf Türkçe Ders Kitabında verilen yazma etkinliklerinin üst düzey bilişsel becerileri kazandırma konusunda yetersiz kaldığı dikkat çekmektedir. Üst düzey bilişsel becerilerin geliştirilmesi için kitaplardaki etkinliklerin de öğrencilerin farklı düşünmelerini sağlayacak etkinlikler olması gerekmektedir. Çalışmada özellikle dil bilgisine yönelik etkinliklerin alt düzey bilişsel beceriler sınıfında kaldığı görülmüştür. Bu sebeple özellikle yazma becerisi altında dil bilgisine yönelik hazırlanan etkinliklerde bir farklılaşmaya gidilerek doğrudan bulmayı, seçmeyi, bilmeyi gerektiren etkinlikler yerine öğrencilerin oluşturdukları metinler üzerinden dil bilgisi konularına yönelik etkinlikler verilmelidir.

\section{Kaynaklar}

Anderson, L.W. (1999). Rethinking Bloom's taxonomy: Implications for testing and assessment. ERIC Documents Reproduction Service, 1-24. (ED 435 630).

Anderson, L.W. ve D. Krathwohl (Ed.). (2001). A taxonomy for learning, teaching, and assessing: a revision of Bloom's taxonomy of educational objectives. U.S.: Addison Wesley Longman, Inc.

Anderson, L.W. (2005). Objectives, evaluation, and the improvement of education. Studies in Educational Evaluation. 31, 102-113.

Aslan, C. (2011). Soru sorma becerilerini geliştirmeye dönük öğretim uygulamalarının öğretmen adaylarının soru oluşturma becerilerine etkisi. Eğitim ve Bilim, 36(160), 236-249.

Aydın, N., Yılmaz, A. (2010). Yapılandırııı yaklaşımın öğrencilerin üst düzey bilişsel becerilerine etkisi. Hacettepe Üniversitesi Eğitim Fakültesi Dergisi, 39, 57-68.

Başbay, M. (2008). Yenilenmiş taksonomiye göre düzenlenmiş öğretim tasarımı dersinde projeye dayalı öğretimin öğrenme ürünlerine etkisi. Yayımlanmış Doktora Tezi, Ankara: Hacettepe Üniversitesi.

Benzer, A. (2017). Cumhuriyet dönemi karşılaştırmalı ana dili öğretim programları. A. Güzel (Edt.), Başlangıçtan Günümüze Türkçenin Eğitim Öğretim Tarihi Araştırmaları, (s.s. 301-350), Ankara: Akçağ Yayınları.

Beyreli, L., Sönmez, H. (2017). Bloom taksonomisi ve yenilenmiş Bloom taksonomisi ile ilgili Türkiye'de yapılan çalışmaların odaklandığı araştırma konuları. International Journal of Languages' Education and Teaching, 5(2), 213-229. 


\section{8. sınıf Türkçe ders kitabında yer alan yazma etkinliklerinin yenilenmiş Bloom taksonomisine göre incelenmesi}

Bloom, B. S. (Ed.) (1956). Taxonomy of educational objectives, handbook 1: Cognitive domain, (2nd Edition), London: Longman Publishing

Bümen, N. T. (2007). Effects of the original versus revised Bloom's taxonomy on lesson planning skills: A Turkish study among pre-service teachers, Review of Education, 53, 439-455.

Büyüköztürk, Ş., Çakmak, E. K., Akgün, Ö. E., Karadeniz, Ş., Demirel, F. (2013). Bilimsel araştırma yöntemleri. (14. Baskı). Ankara: Pegem Akademi Yayıncılık.

Creswell, J. W. (2017). Araştırma deseni, nitel, nicel ve karma yöntem yaklaşımları. S.B. Demir (Çev. Edt.), (3. Baskı), Ankara: Eğiten Kitap

Çakır, N. (2013). Üniversite eğitiminin üst düzey düşünme becerilerinin gelişimine etkisi. Doktora Tezi, Ankara: Hacettepe Üniversitesi

Demir, P. (2015). Yenilenmiş Bloom taksonomisine göre 2005 yılı Sosyal Bilgiler öğretim programında yer alan kazanımlar ve seviye belirleme sınav soruları. Yayımlanmamış Yüksek Lisans Tezi, Samsun: On Dokuz Mayıs Üniversitesi.

Durukan, E., Demir, E. (2017). 6, 7 ve 8. sınıf Türkçe dersi çalışma kitaplarındaki etkinliklerin Bloom'un yenilenmiş taksonomisine göre sınıflandırılması. Uluslararası Türkçe Edebiyat Kültür Eğitim Dergisi, 6(3), 1619-1629.

Eroğlu, D. (2013). 6., 7. ve. 8. sınıf Türkçe çalışma kitaplarındaki dil bilgisi soruları ve kazanımlarının yenilenmiş Bloom taksonomisine göre değerlendirilmesi. Ankara: Başkent Üniversitesi. Yüksek Lisans Tezi.

Forehand, M. (2010). Bloom's taxonomy. M.Orey (Ed.), Emerging perspectives on learning, teaching and technology. (ss.41-47), Switzerland: Global Text.

Güneş, F. (2012). Öğrencilerin düşünme becerilerini geliştirme. Türklük Bilimi Araştırmaları, 32, 127146.

Güneş, F. (2013). Türkçe öğretimi yaklaşımlar ve modeller. (1. Baskı), Ankara: Pegem Akademi Yayınları

Huitt, W. (2011). Bloom et al.'s taxonomy of the cognitive domain. educational psychology interactive. http://www.edpsycinteractive.org/topics/cogsys/bloom.html [pdf] adresinden 21.12.2019 tarihinde erişildi.

Karadağ, Ö. Maden, S. (2014). Yazma eğitimi: kuram, uygulama, ölçme ve değerlendirme. A. Güzel ve H. Karatay (Ed.), Türkçe öğretimi el kitabı. (2. Baskı), (ss.265-306), Ankara: Pegem Akademi Yayıncilık

Krathwohl, D.R. (2002). A revision of Bloom taxonomy: an overview, Theory into Practice, 41(4), 212218.

Mecit, Ö. (2006). 7E öğrenme evresi modelinin beşinci sınıf öğrencilerinin eleştirel düşünme yeteneği gelişimine etkisi. Ankara: Ortadoğu Teknik Üniversitesi, Doktora tezi.

Milli Eğitim Bakanlığı (MEB), (2006). ilköğretim Türkçe dersi öğretim programı ve kılavuzu (6, 7 ve 8. Sınıflar). Ankara: MEB Yayınları

Milli Eğitim Bakanlığı (MEB), (2018). Türkçe dersi öğretim programı. Ankara: MEB Yayınları

Nickerson, R. (1988). On improving thinking through instruction. Review of Research in Education. 15, 3-57.

Ulum, H. (2017). MEB ilkokul 2, 3 ve 4. sınıf Türkçe ders ve çalışma kitaplarında yer alan etkinliklerin yenilenmiş Bloom taksonomisine göre incelenmesi. Mersin: Mersin Üniversitesi. Yüksek Lisans Tezi,

Yıldırım, A. Şimşek, H. (2013). Sosyal bilimlerde nitel araştırma yöntemleri. (9. Baskı), Ankara: Pegem Akademi Yayınları.

Yıldız, D. Ç. (2015a). Türkçe dersi sınav sorularının yeniden yapılandırılan Bloom taksonomisine göre analizi. Gaziantep University Journal of Social Sciences, 14(2), 479-497.

Yıldız, N. (2015b). İlkokul sosyal bilgiler öğretiminde başarılı zeka kuramına dayalı etkinliklerin düşünme becerilerine etkisi. Konya: Necmettin Erbakan Üniversitesi. Doktora tezi. 


\section{Introduction}

\section{Extended Abstract}

Language, which we express ourselves in the best way, is also an important source in the formation and transmission of our thoughts. It is a known fact that language and thought are not separated from each other and that both feed each other. In the recent years, when the mental activities of the learner gained importance in the learning process with the introduction of a learnercentered education approach, the development of language and thinking skills that interact with each other has become the most important purpose of modern education approaches. In the recently updated curricula, language skills are not only the development of listening, speaking, reading and writing skills; at the same time, it has been emphasized that it plays an active role in the development of some high level skills such as thinking, ranking, classification and questioning. Among the language skills that contribute to the development of high-level thinking, writing is a skill that requires some high-level thinking skills. Although each skill contributes greatly to the development of our minds, writing skill, which includes skills such as producing new things, questioning, developing, expressing thoughts, analytical thinking, contributes greatly to the development of high-level thinking skills. Writing is a language skill that provides high-level thinking skills. The material and assessment used in the learning process should be aimed at developing these skills in order to gain high level thinking skills. In the cognitive sense, the first taxonomy which we can classify measurement, assessment and activities belongs to Bloom. As a result of the changes in education, the original taxonomy remained inadequate at some points and some restrictions on the original taxonomy were removed and a draft of the revised taxonomy was formed in 1997. Bloom's taxonomy is frequently used in the development and evaluation of high-level thinking skills. In this study, it was aimed to determine the extent to which the writing activities in the 8th Grade Turkish Textbook contributed to the high level thinking skills and the distribution of the cognitive skill levels in the writing activities by considering the cognitive skill levels and knowledge dimension of the revised Bloom Taxonomy.

\section{Method}

This study is organized according to the qualitative research pattern. Qualitative research is "an approach to a social or human problem to discover and understand the meanings that individuals or groups attribute" (Creswell, 2017: 4). The sample of the study consists of writing activities in 8th Grade Turkish Textbook published in 2018. The activities are limited with the cognitive skill levels and knowledge dimension of the Revised Bloom Taxonomy. In this study, document analysis, which is one of the data collection methods, was used. Descriptive analysis, one of the qualitative data analysis methods, was used in the analysis of the data.

\section{Result and Discussion}

In this study, it is determined that the writing activities were at the highest (\%32) creation level and at the least (\%6) evaluation level. It is also determined that activities in the creating level are aimed producing and creating something new whereas activities in the remembering level are aimed at the acquisition of grammar given under the writing skills. It was found that $61 \%$ of the activities belong to lower level and $39 \%$ to upper level of cognitive levels. It was seen that the activities aimed at improving the writing skills were directed towards the upper level cognitive steps and the activities related to grammar were directed towards the lower level cognitive steps. It has been found that the studies aimed at finding, marking and knowing the elements of the direct are in the remembering level. It is determined that there are few activities that can lead students to analytical, critical and creative thinking. As a matter of fact, Eroğlu (2013), in her study examining grammar activities according to Bloom's taxonomy, found that grammar activities address lower level cognitive skills and there is no activity corresponding to high level cognitive step. Ulum (2017) examined the activities in the 2nd, 3rd and 4th grade books within the framework of Bloom's taxonomy and it was found that the activities addressed lower level cognitive skills rather than high level cognitive skills. In the distribution of writing activities, especially in the 6th and 7th grades, 
8. sınıf Türkçe ders kitabında yer alan yazma etkinliklerinin yenilenmiş Bloom taksonomisine göre incelenmesi

there was a decrease in the number of activities at the 8th grade level. This is due to the fact that the activities of incoherency in the 8th grade is too many, but they are not included in the study due to the lack of gains for the 8th grade writing skills in the curriculum. Although the curriculum emphasizes high level cognitive skills, it is noteworthy that the writing activities given in the 8th Grade Turkish Textbook are insufficient for acquiring high level cognitive skills. 